\title{
The Lakhra Anticline- An Active Structure of Pleistocene to Holocene Age in Southern Pakistan
}

Scientific Investigations Report 2006-5279 


\section{The Lakhra Anticline- An Active Structure of Pleistocene to Holocene Age in Southern Pakistan}

By William F. Outerbridge and John R. SanFilipo

U.S. Geological Survey

Rafiq Ahmed Khan

Geological Survey of Pakistan

The report updates USGS Open-File Report 89-427 but does not supersede it.

Scientific Investigations Report 2006-5279 


\section{U.S. Department of the Interior DIRK KEMPTHORNE, Secretary}

\section{U.S. Geological Survey \\ Mark D. Myers, Director}

\section{U.S. Geological Survey, Reston, Virginia: 2007}

For product and ordering information:

World Wide Web: http://www.usgs.gov/pubprod

Telephone: 1-888-ASK-USGS

For more information on the USGS - the Federal source for science about the Earth, its natural and living resources, natural hazards, and the environment:

World Wide Web: http://www.usgs.gov

Telephone: 1-888-ASK-USGS

Any use of trade, product, or firm names is for descriptive purposes only and does not imply endorsement by the U.S. Government.

Although this report is in the public domain, permission must be secured from the individual copyright owners to reproduce any copyrighted materials contained within this report.

Suggested citation:

Outerbridge, W.F., SanFilipo, J.R., and Khan, R.A., 2007, The Lakhra anticline-An active structure of Pleistocene to Holocene age in southern Pakistan: U.S. Geological Survey Scientific Investigations Report 2006-5279, 16 p., available only online. 


\section{Contents}

Abstract
Introduction
Stratigraphy of the Lakhra Anticline.
Historic and Current Interpretation of Stratigraphy
Tectonic Activity
Conclusions
References Cited

\section{Figures}

[Figures follow References Cited]

1. Shaded-relief map of part of southern Pakistan showing the locations of the study area near the Lakhra anticline, places mentioned in the text, and the triple junction of the Arabian, Eurasian, and Indian

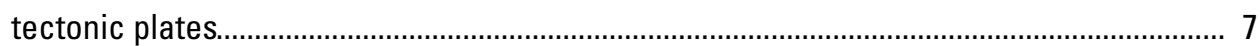

2. Geologic sketch map of the Lakhra anticline and vicinity, Sindh, Pakistan......................... 8

3. Correlation chart showing the age, general lithology, and current and former stratigraphic nomenclature for deposits in the Lakhra anticline, Pakistan..

4-10. Photographs showing-

4. The gorge cut by Lakhra Nala through the Lakhra anticline, Pakistan........................ 11

5. The Band Virah fault face, Pakistan................................................................... 12

6. The view southward along the Band Virah fault, Pakistan.......................................... 12

7. The Band Virah chauki (police station), Pakistan....................................................... 13

8. The interior of the northeast side of the Lakhra anticline, Pakistan............................. 13

9. The view eastward down the dip slope on the Laki Formation, Pakistan...................... 14

10. Lakhra Nala, Pakistan, near its lower end.................................................................. 14

11. Drainage map of the Lakhra anticline, Pakistan, showing the trace of the anticline axis and all second-order and higher order drainages................................ 15

12. Profiles of selected drainages in the area of the Lakhra anticline, Pakistan...................... 16

\section{Conversion Factors}

\begin{tabular}{lll}
\hline Multiply & By & To obtain \\
inch (in.) & 2.54 & centimeter $(\mathrm{cm})$ \\
mile (mi) & 1.609 & kilometer $(\mathrm{km})$ \\
& & \\
centimeter (cm) & 0.3937 & inch (in.) \\
meter (m) & 3.281 & foot (ft) \\
kilometer $(\mathrm{km})$ & 0.6214 & mile $(\mathrm{mi})$ \\
\hline
\end{tabular}




\title{
The Lakhra Anticline-An Active Structure of Pleistocene to Holocene Age in Southern Pakistan
}

\author{
By William F. Outerbridge, ${ }^{1}$ John R. SanFilipo, ${ }^{2}$ and Rafiq Ahmed Khan ${ }^{3}$
}

\begin{abstract}
The Lakhra anticline is a breached north-trending structure northwest of Hyderabad in Sindh Province, Pakistan. About 340 meters (m) of Paleocene to Holocene strata have been eroded from the core of the anticline. North-trending normal faults transect the anticline at a low angle, are vertical, and form a set of nested grabens.

Lakhra Nala and Siph Nala were formed where antecedent streams eroded the nalas (canyons, gullies, ravines, or watercourses and the streams in them) as the anticline rose. Lakhra Nala flows onto the Indus River flood plain, which is accumulating about $6.1 \mathrm{~m}$ of alluvium per 1,000 years. If the anticline rose at an equivalent rate, it started to rise about 60,000 years ago.
\end{abstract}

\section{Introduction}

In 1985, the U.S. Geological Survey (USGS), under an agreement with the U.S. Agency for International Development and in cooperation with the Geological Survey of Pakistan (GSP), began a coal exploration project in southern Pakistan. This report uses unpublished data from geologic mapping by Rafiq Ahmed Khan, exploration drilling, and structural and stratigraphic studies resulting from the project.

The focus of the report is the Lakhra anticline, which is a breached, north-trending structure northwest of Hyderabad in Sindh Province, southern Pakistan (fig. 1; figures 1-12 follow "References Cited"). The anticline is about 30 kilometers $(\mathrm{km})$ wide and $100 \mathrm{~km}$ long, and its highest points are about $0.2 \mathrm{~km}$ above sea level.

The earliest systematic geologic investigation in the Hyderabad region was that of Blanford (1879), who produced a geologic map showing the Lakhra anticline at a standard British Treasury map scale of 16 miles to the inch. Nuttall (1925) made a detailed study of the paleontology and stratig-

\footnotetext{
${ }^{1}$ Retired, U.S. Geological Survey, Mail Stop 956, National Center, Reston, VA 20192, U.S.A. (e-mail: Outerbridge@aol.com).

${ }^{2}$ U.S. Geological Survey, Mail Stop 956, National Center, Reston, VA 20192, U.S.A. (e-mail: jsan@usgs.gov).

${ }^{3}$ Geological Survey of Pakistan, Karachi, Pakistan. (e-mail: iak1982@ yahoo.com).
}

raphy of Tertiary units in the Meting area, which is just south of the Lakhra anticline (figs. 1, 2). During the Hunting Survey Corporation project, researchers mapped the anticline area at a scale of 1:253,440 ( 1 inch $=4$ miles) (Jones, 1960). Outerbridge and others (1991) showed that the Basal Laki Laterite of Nuttall (1925) is a coal-bearing clastic deposit and named it the Sohnari Formation. The geology of the area around the Lakhra anticline is shown in figure 2.

The tectonic development of Pakistan has been summarized by Farah and DeJong (1979), Jacob and Quittmeyer (1979), Farah and others (1984), and Yeats and Lawrence (1984). The Lakhra anticline is a gentle fold between the Laki Range and the Indus River, and it appears to be the easternmost structure resulting from collisions of the Arabian, Eurasian, and Indian tectonic plates (fig. 1).

Our observations suggest that faulting and uplift of the Lakhra anticline began in the Pleistocene and continue today (Outerbridge and Khan, 1988, 1989a,b). This report uses stratigraphic and geomorphic data collected during exploration for coal resources to interpret the age of the anticline and updates the report by Outerbridge and Khan (1989b), adding more evidence of continuing tectonic activity, topographic data from SanFilipo, and stream data.

\section{Stratigraphy of the Lakhra Anticline}

\section{Current Nomenclature}

Stratigraphic nomenclature and the general rock types exposed in the Lakhra anticline are shown in figure 3. In general, sandy intervals are unconsolidated to indurated and may on occasion run like water into mines and drill holes; shales are indurated to lithified but can usually be broken by hand; rubbly bedded limestones break along shale partings and evenly bedded limestones are strongly lithified.

From oldest to youngest, the units exposed in the Lakhra anticline are summarized below.

Bara Formation (Paleocene) of the Ranikot Group.-The oldest unit exposed in the core of the Lakhra anticline is the Bara Formation of Paleocene age. It consists of sandstone, siltstone, shale, underclay, and coal and is the main source of coal in the anticline. 


\section{Lakhra Formation (upper Paleocene) of the Ranikot} Group.-Conformably overlying the Bara Formation is the Lakhra Formation of late Paleocene age. It consists of evenly bedded limestone and calcareous shale and is richly fossiliferous.

Sohnari Formation (upper Paleocene) of the Ranikot Group.-The Sohnari Formation was redefined by Outerbridge and others (1991). Formerly called the Basal Laki Laterite (largely because of its deep red color), the Sohnari Formation consists of sandstone, conglomerate, shale, coal, and underclay. It is fossiliferous, and we have observed clams in growth position deep in the coal. The Sohnari interfingers with the Lakhra Formation.

Meting Limestone Member (upper Paleocene) of the Laki Formation.-The Meting Limestone Member is the lowest of three members composing the marine Laki Formation in the area of the Lakhra anticline. The Meting Limestone Member overlies the Sohnari Formation along a sharp conformable contact. The Meting Limestone Member consists of richly fossiliferous rubbly bedded limestone with shale partings. As the partings increase in number and thickness, the Meting Limestone Member grades into the Meting Shale Member.

Meting Shale Member (upper Paleocene and lower Eocene) of the Laki Formation.-The Meting Shale Member is a richly fossiliferous calcareous shale with common to abundant limestone concretions that form beds near the base and the top of the unit. As limestone becomes more abundant and shale less so, the Meting Shale Member grades upward into the Laki Limestone Member.

Laki Limestone Member (upper Eocene) of the Laki Formation.-The Laki Limestone Member is a richly fossiliferous rubbly bedded limestone.

Manchhar Formation (Pliocene to Pleistocene). - The Manchhar Formation, as it is called in Sindh Province, or the Siwalik Group, as it is known in northern Pakistan (Shah, 1977), is probably of Pliocene to Pleistocene age (Jones, 1960). It unconformably overlies the Laki Formation around the Lakhra anticline. It consists of gravel, sand, and clay with large fossil bones and petrified wood.

Older alluvium (Pleistocene to Holocene).-Alluvial deposits are considered older if they are erosionally dissected and younger if they are being deposited. Absolute ages of the deposits are not implied. Near the Lakhra anticline, terrace deposits along Siph Nala and Lakhra Nala and alluvial fan deposits along the east side of the anticline are dissected older alluvium. The terrace deposits may be as much as $9 \mathrm{~m}$ thick downstream from the junction of Siph and Lakhra Nalas and consist of limestone gravel, sand, silt, and clay.

Younger alluvium (Pleistocene to Holocene).- Younger alluvium occupies streambeds and active flood plains. It consists mostly of sand, silt, and clay; gravel is in the beds of lower order streams.

\section{Historic and Current Interpretation of Stratigraphy}

Evidence bearing on the history of the Lakhra anticline includes the following: (1) the stratigraphy of the Laki Formation, (2) the character of the Sohnari Formation, (3) the change in thickness of the Lakhra Formation from place to place, and (4) the ages of the units involved in the development of the Lakhra anticline. The first person to consider any of these lines of evidence in detail was Nuttall (1925), and his interpretation has been followed ever since. New data suggest another interpretation.

Stratigraphy of the Laki Formation.-Nuttall (1925, p. 427-428) stated that successively younger units of the Laki Formation overlap successively older units of the Ranikot Formation northward from Thatta, which is south of the Lakhra anticline and Meting (fig. 1); this statement was based on what he thought was the disappearance of the Meting Limestone and the Meting Shale northward, so that, in the Laki Range, the Laki Limestone overlies the Lower Ranikot (Bara Formation of current usage). Nuttall used studies of larger foraminifera to support his finding of a hiatus between the two formations.

We have observed that the Meting Limestone Member of the Laki Formation is thick and extends across the Lakhra anticline. Usmani (1983) studied the smaller foraminifera in cores from two drill holes in the Lakhra anticline and found that the lowest 16.5 meters (m) of the Laki Formation is in the Globorotalia pseudomenardii planktonic foraminiferal zone of late Paleocene age. Her findings do not support a hiatus between the Lakhra Formation (equivalent to the Upper Ranikot Formation of Nuttall, 1925) and the Laki Formation. Instead, the Sohnari Formation interfingers with the Lakhra Formation and conformably underlies the Laki Formation.

Character of the Sohnari Formation.-Nuttall (1925, p. 427) stated that the striking red unit at the base of the Laki Formation was a Laterite, which was called the Basal Laki Laterite and which represented "a land period accompanied by erosion, between the marine deposition of the Upper Ranikot and that of the Laki Series." The Basal Laki Laterite Member has been redefined as the Sohnari Formation between the Lakhra Formation (below) and the Laki Formation (Outerbridge and others, 1991).

Cores drilled by the GSP and the USGS provided evidence that the Sohnari Formation is a coal-bearing unit (Outerbridge and others, 1991), and the cores show an upward stratigraphic progression through shale, silt, sand, underclay, coal, and shale that interfingers with the Lakhra Formation. Field observation shows that the red color of outcrops of the Sohnari Formation is due to iron oxide that resulted from weathering of pyrite in beds above the coal. 
Nuttall (1925) stated that the hiatus represented by the Basal Laki Laterite is least near Thatta (fig. 1) and increases northward and westward and that the Upper Ranikot Formation, or Lakhra Formation of present usage, thins northward and northwestward from near Meting.

Change in thickness of the Lakhra Formation.-Interpretation of drilling data indicates that the Lakhra Formation thickens northward from near Jherruck and southward from the Lakhra anticline and appears to thin northwestward in the northern part of the Lakhra anticline (Outerbridge and Khan, 1989b, fig. 5). It is $170 \mathrm{~m}$ thick between Baran Nadi and Siph Nala. The thickness data do not support Nuttall's hypothesis of erosional removal of the Lakhra Formation across the Lakhra anticline.

Ages of units involved in the development of the Lakhra anticline.-Geologic mapping by members of the Hunting Survey Corporation project (Jones, 1960) and mapping done by Rafiq Ahmed Khan (Geological Survey of Pakistan, unpub. data) show that the Manchhar Formation of Pliocene to Pleistocene age is faulted and raised as a result of the rising of the Lakhra anticline (Outerbridge and Khan, 1989a). The Manchhar Formation is a widespread unit having many possible sources and environments of deposition, but near the Lakhra anticline, it is thought to be alluvium from one or more river systems (Jones, 1960). The topography of the region during Manchhar deposition likely was much as it is now west of the Lakhra anticline. Streams from the area of the present Laki Range flowed eastward across a gravelly plain into an estuary now occupied by the Indus River and its sediments. It is likely that deposition of the Manchhar Formation continued well into the Pleistocene and ended in the Lakhra area when the anticline rose enough to make erosion a dominant process.

Older alluvium was deposited as a large alluvial fan on the Manchhar Formation as the Lakhra anticline rose and Lakhra Nala eroded a gorge through those gravels (fig. 4). Now Lakhra Nala has eroded a deep channel through older alluvium to bedrock near the east side of the anticline and is depositing younger alluvium in the lower reach of its channel.

\section{Tectonic Activity}

According to Warwick and others (1998) and Clyde and others (2003), the Indian tectonic plate collided with the Eurasian plate in the time interval between the late Paleocene and the middle Eocene. They and Farah and DeJong (1979), Farah and others (1984), Haq and Milliman (1984), and Yeats and Lawrence (1984) agreed that the process of collision is continuing and that the anticlines that approximately parallel the suture zone are results of the collision of the two plates. Another collision, among the Arabian, Eurasian, and Indian plates, also is in progress, and the folding of some of the struc- tures in southern Pakistan is attributed to collision between the Indian and Arabian plates; among these structures is the Lakhra anticline. Jacob and Quittmeyer (1979) suggested that a triple junction joins the Indian, Arabian, and Eurasian plates north of Karachi and west of Hyderabad, Pakistan, where the net motion resulting from the collision of the three plates is slippage to the northeast at a rate of 1.8 centimeters per year (fig. 1).

The Lakhra anticline is replete with surface indications of faulting (figs. 2, 5, 6, and 7). Some of the traces are exhumed faults, but others appear fresh. The faults trend northward, are generally vertical, and have upthrown beds on the east side on the eastern limb of the anticline and on the west side on the western limb of the anticline, forming a set of nested grabens that breach the anticline. Faults crossing Siph Nala interrupt the gradient of the stream. Other faults control the course of Darkhara Nala.

Seismic activity in the area of the Lakhra anticline supports the interpretation that the area is tectonically active. The strongest recorded earthquake in the vicinity of Hyderabad had an intensity of VI (Quittmeyer and others, 1979). Earthquakes of intensity II to III occur in the area every few weeks, according to reports from the earthquake observatory at the University of Sindh, which is on the east side of the Lakhra anticline, near Hyderabad.

\section{Geomorphology}

The Lakhra anticline is a breached anticline. The interior has been eroded, forms a broad basin, and exposes strata as low as the Bara Formation (figs. 2, 3, and 8). Low rounded hills and broad lowlands form on the Bara Formation. Broad benches form on shale and sandstone of the Lakhra Formation; beds of limestone form ledges and underlie dip slopes. The generally nonresistant Sohnari Formation crops out in low rounded hills and in steep slopes of shale, siltstone, and sandstone under the scree of the overlying limestones. Where thick, the limestone beds of the Laki Formation form cliffs; elsewhere, they form ledges. They underlie extensive dip slopes that are interrupted by steep-walled nalas (canyons, gullies, ravines, or watercourses and the streams in them) on the east side of the anticline (fig. 9) and shale slopes and limestone ledges near the core of the anticline. Dissected eastward sloping benches, terraces, pediments, and the dissected alluvial fan of Lakhra Nala are formed of older alluvium. Sediments in nalas, on flood plains, and on most alluvial fans are composed of younger alluvium (fig. 10).

Streams in and around the Lakhra anticline flow only during the monsoon season and not always then. Lakhra Nala has cut a gorge across the eastern side of the Lakhra anticline and drains its core and an extensive area to the west, the 
area's largest drainage basin (fig. 11). The drainage pattern is generally radial around the Lakhra anticline. North and south of the Lakhra Nala drainage basin, the main drainage divide defines the geomorphic axis of the anticline. Northwest of the anticline, streams flowing from the Laki Range are diverted around the north end of the anticline and flow toward the Indus River or into a low area just north of the anticline.

Streams south of the Lakhra Nala drainage basin flow toward Baran Nadi or toward the Indus River. None enter the Indus River, which commonly is in flood during the summer because of snowmelt from the Himalaya Mountains.

The Lakhra Nala drainage system heads in the Laki Range and crosses a broad flat plain without well-defined channels. Check dams trap the summer monsoon storm flows (which come most years), and arrays of check dams define the drainage above Band Virah (D, fig. 11). Sheet flow runs toward Band Virah. Siph Nala rises southeast of Band Virah and begins its eastward flow just east of Band Virah. It joins Tel Nala, which flows from a dendritic drainage, and the two nalas become Lakhra Nala (B, fig. 11). Lakhra Nala flows through a gorge across the topographically highest part of the anticline, cuts through its old alluvial fan (fig. 10), and spills onto the Indus flood plain but does not reach the Indus River channel.

Stream profiles (fig. 12) are drawn from existing topographic maps from the Indus River (A) to the junction of Siph and Tel Nalas (B), from there to the head of Tel and Khlori Nalas (C), along Siph Nala to Band Virah (D) and the edge of the mapped area (E), and up Darkhara Nala to its head (K). The profile along Tel and Khlori Nalas reflects the headward steepening of the stream profile as it approaches the rim of the interior basin of the Lakhra anticline.

Darkhara Nala rises on a limestone-capped plateau $(\mathrm{K})$, flows southeast into an alluvial flat (J) on another limestone bed (I), then southwest and west downdip to a fault trough $(\mathrm{H})$, where it turns north. The nala turns west at the north end of the fault and runs into another fault trough $(\mathrm{G})$, where it again turns north and runs into Siph Nala (F). The gradient of Darkhara Nala is affected by both stratigraphy and structure, but the headward steepening persists.

In contrast, the gradient of the $36-\mathrm{km}$ reach ( $\mathrm{F}$ to $\mathrm{A}$ ) from the junction of Siph and Darkhara Nalas to the lower end of Lakhra Nala is a fairly uniform $1 \mathrm{~m}$ in $500 \mathrm{~m}$. The gradient is slightly greater near the east side of the anticline in line with a series of short east-flowing nalas. We have not observed faulting along the line and suspect that the steepening may be due to continuing increase of dip on the east side of the anticline. The almost uniform gradient of the nala appears to be a result of continuing uplift in the core of anticline balanced by erosion of the nala.

Faulting (fig. 5) has beheaded Siph Nala at Band Virah (D, fig. 11). West of the fault ridge is an intermittent lake (fig. 2) that stores the runoff from all of the west side of the Lakhra drainage basin. The lake basin is partly filled with alluvium, but the intermittent lake just west of the ridge is still obvious both on the ground and on the profile between points D and $\mathrm{E}$ (fig. 12).

On the east side of the Lakhra anticline, a large alluvial fan is extensively dissected by Lakhra Nala (fig. 2), and the upper end of the fan is largely eroded away. Where the stream emerges from its gorge, it flows on bedrock in a channel well below the surface of the fan, but in the lower part of the fan, it flows in a wide channel on younger alluvium (fig. 2). The distal part of the fan is covered by and interfingers with younger alluvium of the Indus River flood plain.

The mouth of the Indus River is reported to have been 55 $\mathrm{km}$ northeast of Hyderabad in historic time (about 5,000 years ago according to Holmes, 1968), when Lakhra Nala flowed into tidewater. The flood plain of the Indus River now is $25 \mathrm{~m}$ above sea level near Lakhra Nala.

\section{Conclusions}

The Lakhra anticline is recent and likely is still rising. Evidence supporting the idea of a recent rise of the Lakhra anticline includes beds of the Manchhar Formation of Pliocene to Pleistocene age that are uplifted on the anticline, the dissection by Lakhra Nala of the head of its alluvial fan while the foot of the fan is being buried under younger alluvium, the interruption by faults of stream gradients in the anticline, and continuing seismic activity in the region.

An amount and rate of rise of the anticline can be estimated by making three assumptions: (1) the total rise of the anticline is the same as the combined thicknesses of the exposed formations plus the accumulated thickness of the Indus River alluvium above present sea level and the amount of sea-level rise in the past 5,000 years, (2) Siph Nala and Lakhra Nala flowed in approximately their present courses before the anticline started to rise, and (3) the rate of erosion balanced the rate of uplift.

About 340 m of Paleocene to Holocene strata have been eroded from the core of the anticline. The thicknesses involved are as follows: (1) $15 \mathrm{~m}$ of the Bara Formation exposed along Siph Nala, (2) $170 \mathrm{~m}$ of the Lakhra Formation exposed along Siph Nala, (3) $40 \mathrm{~m}$ of the Sohnari Formation projected near Siph Nala from isopachs (Outerbridge and Khan, 1989b), (4) $100 \mathrm{~m}$ of the Laki Formation estimated from drill hole data, and (5) $15 \mathrm{~m}$ of the Manchhar Formation estimated from present outcrops. Adding the $340 \mathrm{~m}$ of erosion to the $25 \mathrm{~m}$ of silt accumulation on the Indus flood plain above present sea level near the mouth of Lakhra Nala (fig. 12) gives a total of about $365 \mathrm{~m}$ for the rise of the Lakhra anticline.

A rate of rise can be estimated by assuming that the anticline has risen at least $30.5 \mathrm{~m}$ in the past 5,000 years; this assumption is based on $5.5 \mathrm{~m}$ of sea-level rise (Wadhams and Munk, 2004) and $25 \mathrm{~m}$ of silt accumulation on the Indus flood plain near the mouth of Lakhra Nala. The rate of $6.1 \mathrm{~m} / 1,000$ years is likely to be low because the place where it was estimated is about $16 \mathrm{~km}$ from the axis of the anticline, but at that 
rate, the anticline took about 60,000 years to rise to its present height.

\section{References Cited}

Blanford, W.T., 1879, The geology of western Sind: India Geological Survey Memoirs, v. 17, p. 1-106.

Clyde, W.C., Khan, I.H., and Gingerich, P.D., 2003, Stratigraphic response and mammalian dispersal during initial India-Asia collision; Evidence from the Ghazij Formation, Balochistan, Pakistan: Geology, v. 31, no. 12, p. 1097-1100.

Farah, Abul, and DeJong, K.A., eds., 1979, Geodynamics of Pakistan: Quetta, Geological Survey of Pakistan, 361 p.

Farah, A., Lawrence, R.D., and DeJong, K.A., 1984, An overview of the tectonics of Pakistan, in Haq, B.U., and Milliman, J.D., eds., Marine geology and oceanography of Arabian Sea and coastal Pakistan: New York, Van Nostrand Reinhold, p. 161-176.

Haq, B.U., and Milliman, J.D., eds., 1984, Marine geology and oceanography of Arabian Sea and coastal Pakistan: New York, Van Nostrand Reinhold, 382 p.

Hearn, P., Jr., Hare, T., Schruben, P., Sherrill, D., LaMar, C., and Tsushima, P., 2001, Global GIS database; Digital atlas of South Asia: U.S. Geological Survey Digital Data Series DDS-62-C, one CD-ROM.

Holmes, D.A., 1968, The Recent history of the Indus: Geographical Journal, v. 134, no. 3, p. 367-382.

Jacob, K.H., and Quittmeyer, R.C., 1979, The Makran region of Pakistan and Iran; Trench-arc system with active plate subduction, in Farah, Abul, and DeJong, K.A., eds., Geodynamics of Pakistan: Quetta, Geological Survey of Pakistan, p. 305-317.

Jones, A.G., ed., 1960, Reconnaissance geology of part of West Pakistan; A Colombo Plan cooperative project conducted and compiled by the Hunting Survey Corporation, Ltd., Toronto, Canada: 550 p., plus a supplement of $172 \mathrm{p}$. (331 ills., 2 tables, 9 pls., 3 sketches, and 25 maps at a scale of $1: 253,440)$.

Kazmi, A.H., 1984, Geology of the Indus Delta, in Haq, B.U., and Milliman, J.D., eds., Marine geology and oceanography of Arabian Sea and coastal Pakistan: New York, Van Nostrand Reinhold, p. 71-84.

Nuttall, W.L.F., 1925, The stratigraphy of the Laki series (lower Eocene) of parts of Sind and Baluchistan (India); with a description of the larger foraminifera contained in those beds: Geological Society of London Quarterly Journal, v. 81 , pt. 3 , p. $417-453$, pls. $23-27$.

Outerbridge, W.F., Fredericksen, N.O., Khan, M. Riaz, Khan, Rafiq Ahmed, Qureshi, M. Jaffar, Khan, M. Zameer, Niamatullah, and Khan, Shafiq Ahmed, 1991, The Sohnari Formation in southern Pakistan, in Stratigraphic notes, 1989-90: U.S. Geological Survey Bulletin 1935, p. 27-40.

Outerbridge, W.F., and Khan, Rafiq Ahmed, 1988, The Lakhra anticline of southern Pakistan is active [abs.]: Geological Society of America Abstracts with Programs, v. 20, no. 7, p. A149.

Outerbridge, W.F., and Khan, R.A. [Rafiq Ahmed], 1989a, Inferred Tertiary to Recent geologic history of Lakhra area, southern Pakistan [abs.]: International Geological Congress, 28th, Washington, D.C., U.S.A., July 9-19, 1989, Abstracts, v. 2, p. 559.

Outerbridge, W.F., and Khan, Rafiq Ahmed, 1989b, The Lakhra anticline-An active feature of Pleistocene to Recent age in southern Pakistan: U.S. Geological Survey Open-File Report 89-427, 32 p.

Quittmeyer, R.C., Farah, Abul, and Jacob, K.H., 1979, The seismicity of Pakistan and its relation to surface faults, in Farah, Abul, and DeJong, K.A., eds., Geodynamics of Pakistan: Quetta, Geological Survey of Pakistan, p. 271-284.

Shah, S.M.I., ed., 1977, Stratigraphy of Pakistan: Geological Survey of Pakistan Memoirs, v. 12, 138 p.

Usmani, Parveen, 1983, Planktonic foraminifera from the Ranikot and basal Laki Formations (Paleocene and early Eocene) of the Lakhra area, Sind, Pakistan: Neues Jharbuch fuer Geologie und Palaeontologie Monatshefte, 1983, no. 7, p. 429-447.

Wadhams, Peter, and Munk, Walter, 2004, Ocean freshening, sea level rising, sea ice melting: Geophysical Research Letters, v. 31, no. 11, citation L11311, 4 p.

Warwick, P.D., Johnson, E.A., and Khan, I.H., 1998, Collision-induced tectonism along the northwestern margin of the Indian subcontinent as recorded in the upper Paleocene to middle Eocene strata of central Pakistan (Kirthar and Sulaiman Ranges): Palaeogeography, Palaeoclimatology, Palaeoecology, v. 142, no. 3-4, p. 201-216.

Yeats, R.S., and Lawrence, R.D., 1984, Tectonics of the Himalayan thrust belt in northern Pakistan, in Haq, B.U., and Milliman, J.D., eds., Marine geology and oceanography of Arabian Sea and coastal Pakistan: New York, Van Nostrand Reinhold, p. 177-198. 
Figures 1-12 


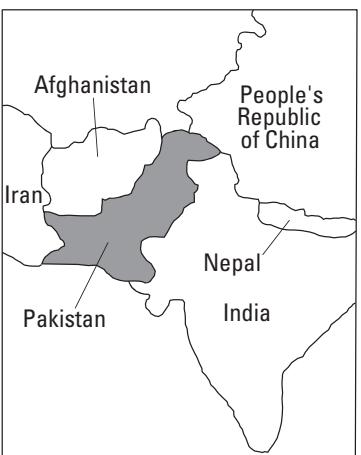

Regional setting of Pakistan



Provinces of Pakistan and area shown in figure 1

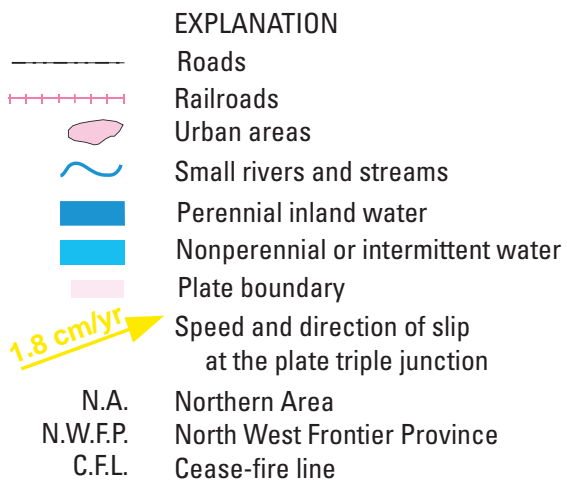

$69^{\circ} \mathrm{E}$



Figure 1. Shaded-relief map of part of southern Pakistan showing the locations of the study area near the Lakhra anticline (red box; the area is shown in more detail in fig. 2), places mentioned in the text, and the triple junction of the Arabian, Eurasian, and Indian tectonic plates. Tectonic plate boundaries and slip-rate information modified from Jacob and Quittmeyer (1979). Base map from Hearn and others (2001). 


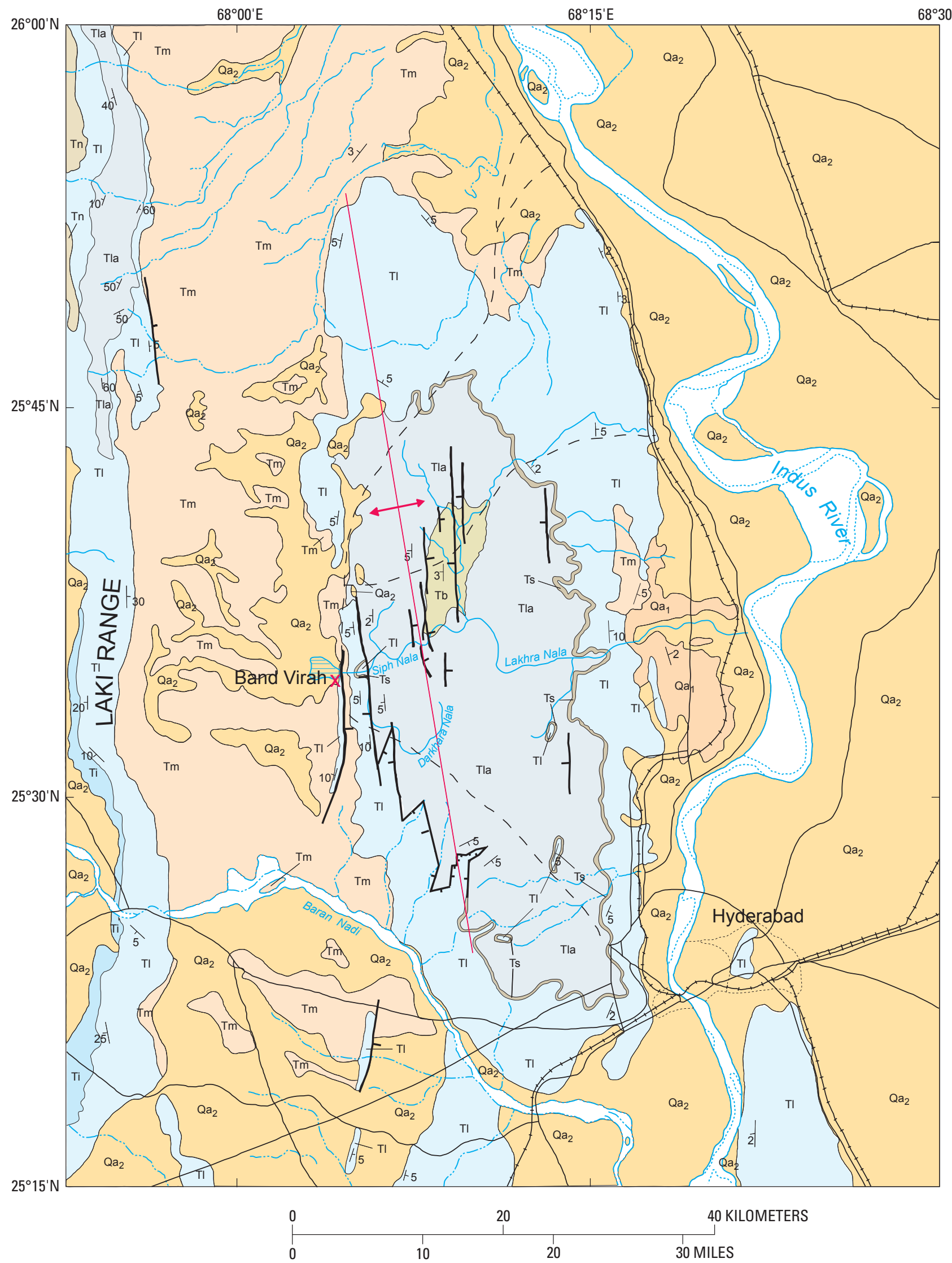

Figure 2. Geologic sketch map of the Lakhra anticline (see trace of anticline axis in red) and vicinity, Sindh, Pakistan. Modified from Jones (1960). 


\section{EXPLANATION}

Qa2

Younger alluvium (Holocene to Pleistocene)-Silt, sand, and gravel

Qa1 Older alluvium (Holocene to Pleistocene)-Conglomerate, gravel, and sand

Tm Manchhar Formation (Pleistocene to Pliocene)-Conglomerate, gravel, and sand

Tn Nari Formation (Eocene)-Sandstone and conglomerate

$\mathrm{Ti}$ Tiyon Formation (Eocene)-Limestone, marl, and shale

TI Laki Formation (Eocene to Paleocene)-Limestone, marl, and shale

Ts Sohnari Formation (upper Paleocene)-Sandstone, shale, and coal

Tla Lakhra Formation (upper Paleocene)-Shale, marl, and limestone

Tb Bara Formation (Paleocene)-Sandstone, shale, and coal

Contact

5) Strike and dip of beds

ـ Fault-Tic on downthrown side

Intermittent lake

$\sim$ Stream

Highway

- - Road

, Railroad

U................. Urban area

$X \quad$ Band Virah (area shown in figures 5, 6, and 7)

Figure 2. Continued. 


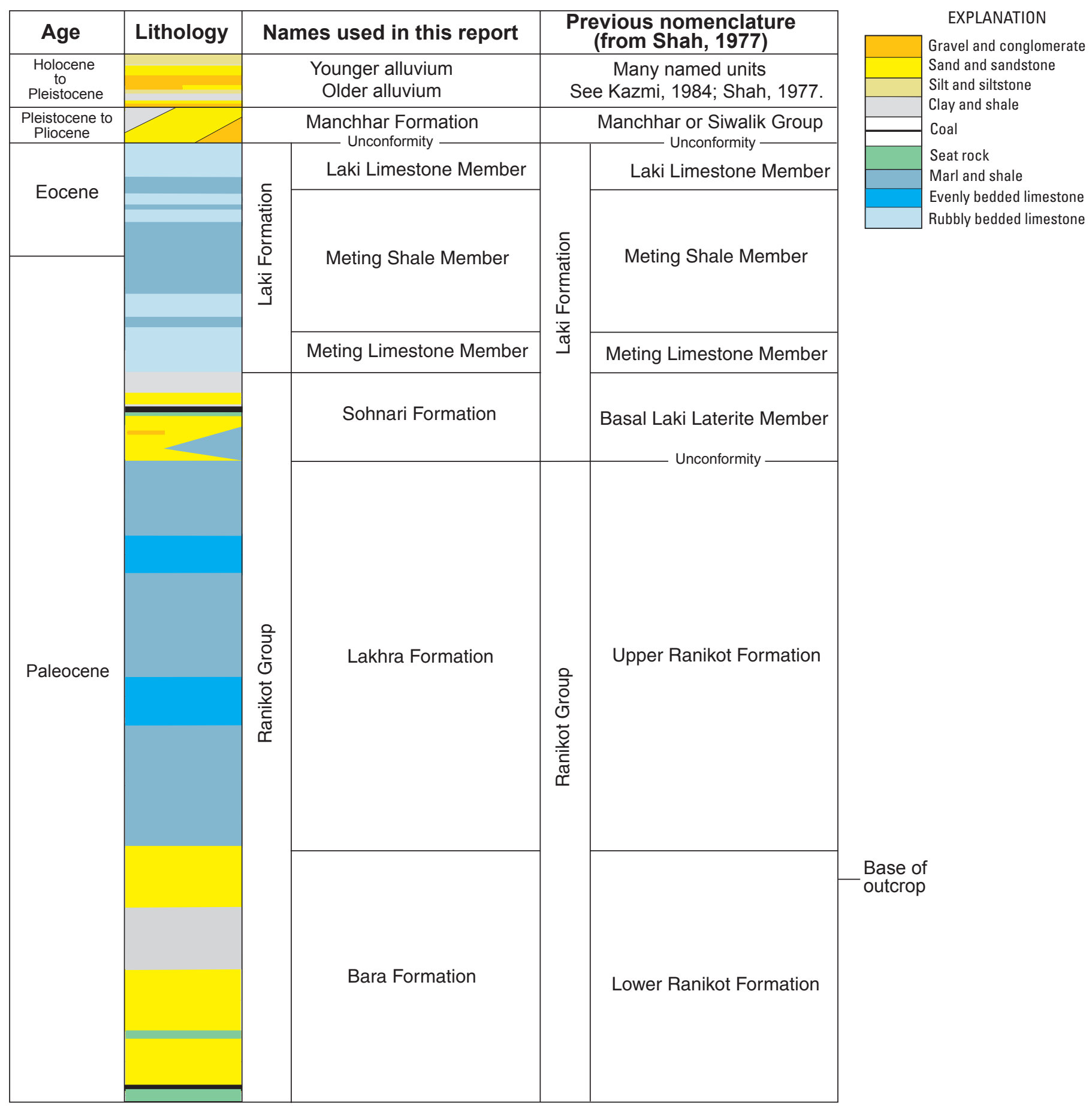

Figure 3. Correlation chart showing the age, general lithology, and current and former stratigraphic nomenclature for deposits in the Lakhra anticline, Pakistan. Most lithologic data are from outcrops, and a label at the right side of the chart indicates the base of outcrop data; lithologic data on the subsurface Bara Formation are derived from examination of drill cores and mine inclines. The Nari and Tiyon Formations, which are present in the Laki Range and are mapped in figure 2, are absent from the Lakhra anticline and are not shown in this correlation chart. 
$\boldsymbol{A}$

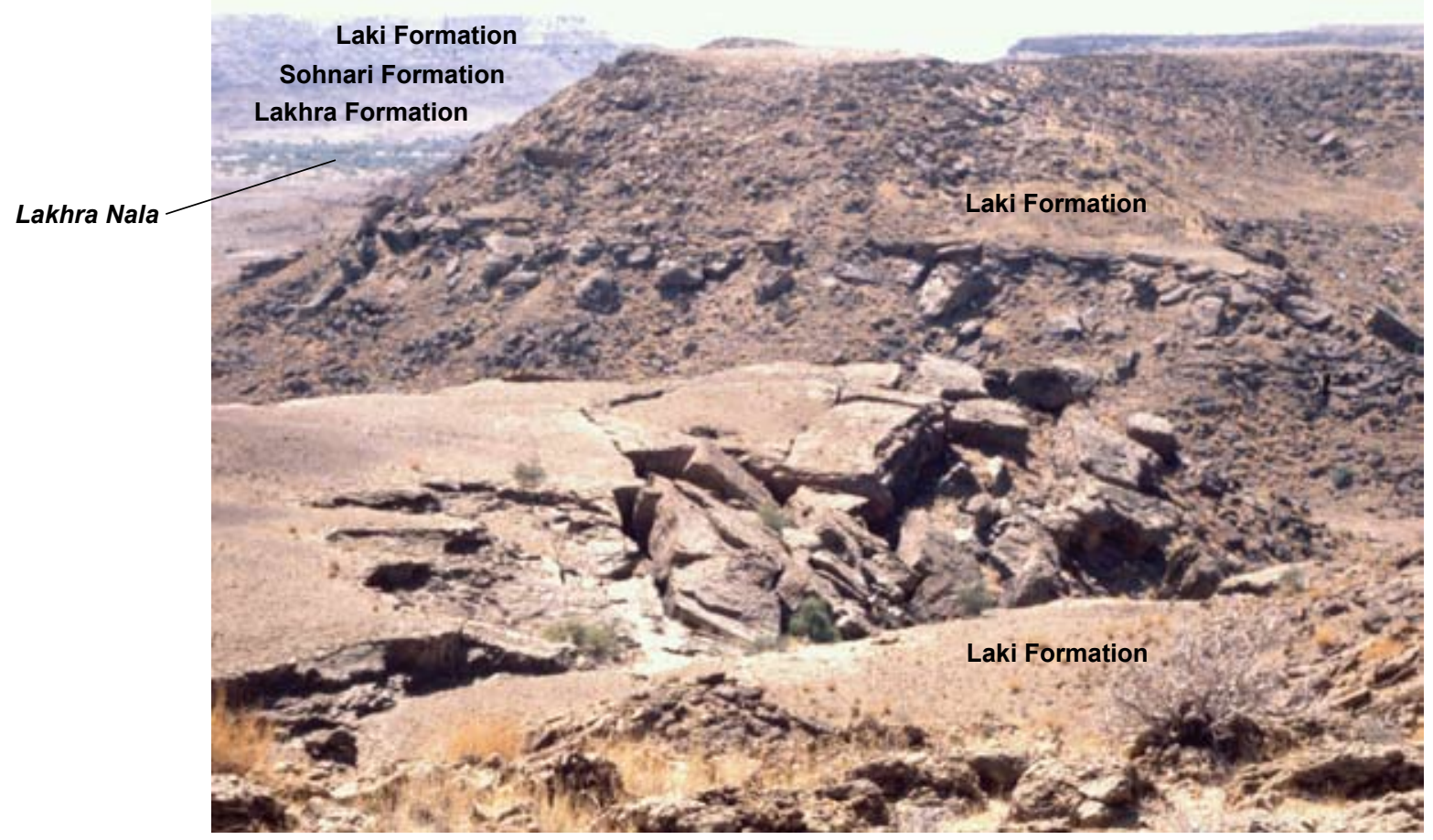

B

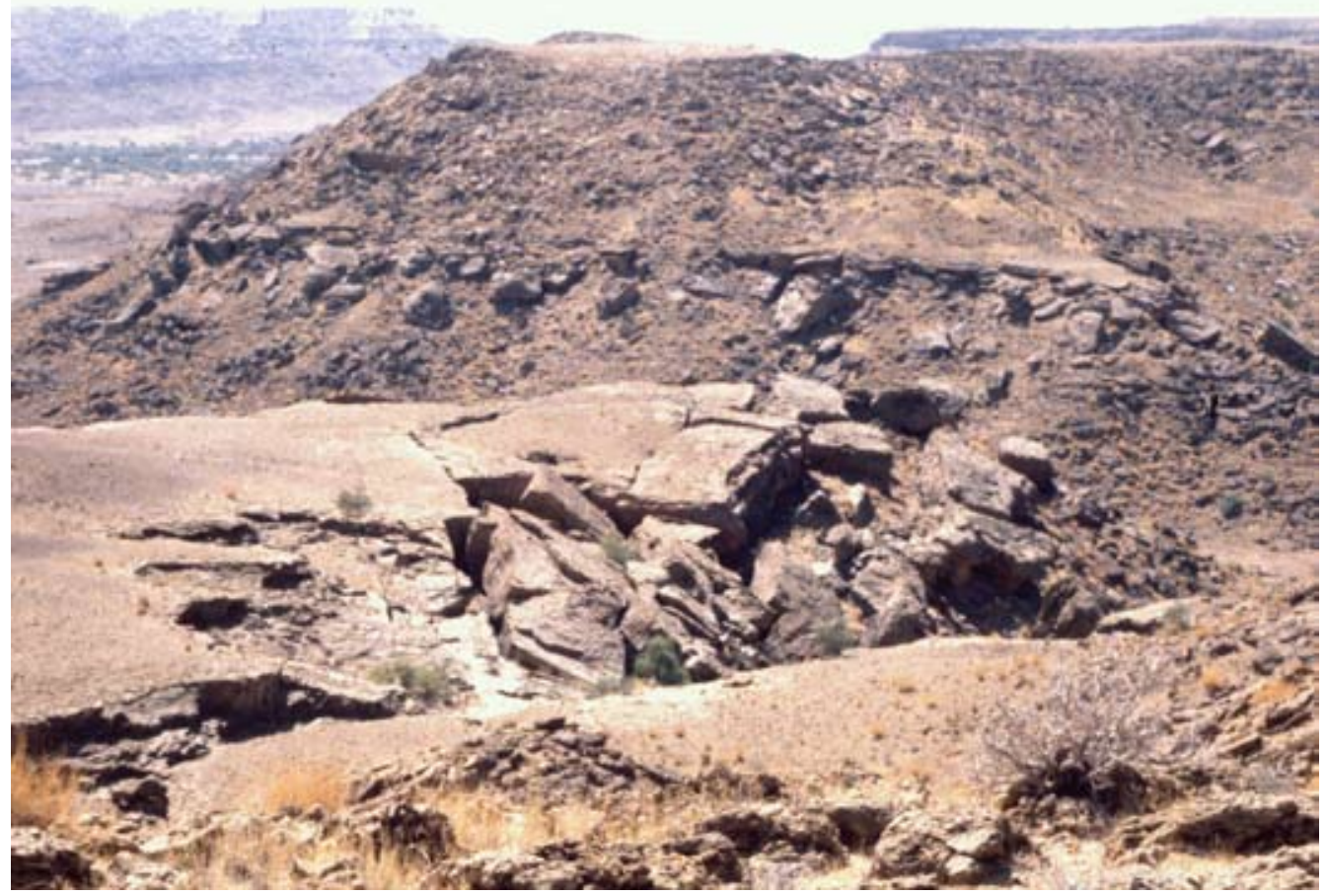

Figure 4. Photograph of the gorge cut by Lakhra Nala through the Lakhra anticline, Pakistan, showing the following features: the Laki Formation in the foreground and composing the upper part of the hill in the background, the Sohnari Formation near the base of the hill in the background, the Lakhra Formation below the Sohnari Formation, and a light streak in greenery indicating the bed of Lakhra Nala. View southwestward. The hill in the background is about $100 \mathrm{~m}$ high. Photograph by W.F. Outerbridge (USGS, 1985). A, Photograph with labels identifying geologic features. $B$, Uninterpreted version of $A$. 


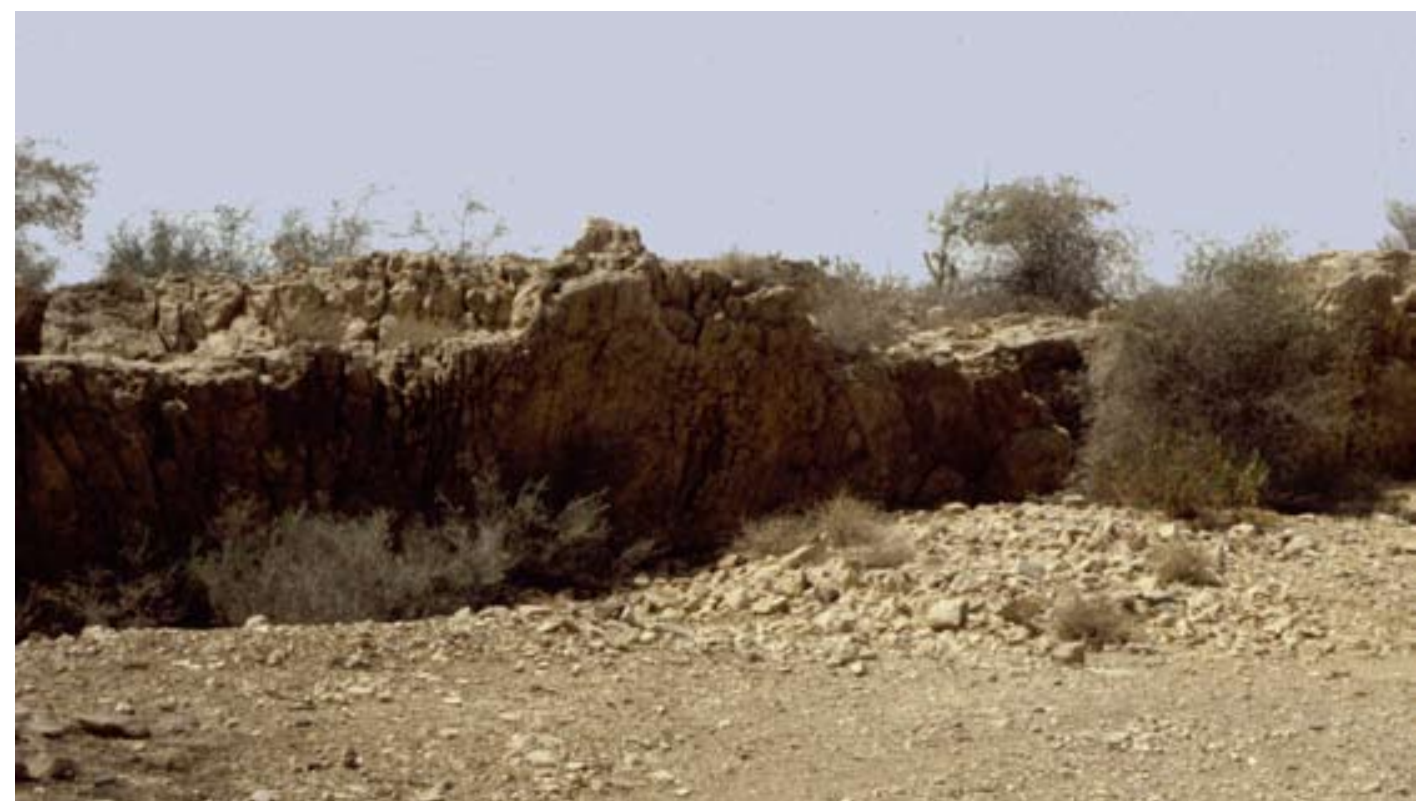

Figure 5. Photograph of the Band Virah fault face, Pakistan, showing the Manchhar Formation in the foreground and the Laki Limestone Member of the Laki Formation in the fault face. The approximate location of the area is shown in figure 2 by the x. Photograph by W.F. Outerbridge (USGS, 1985).

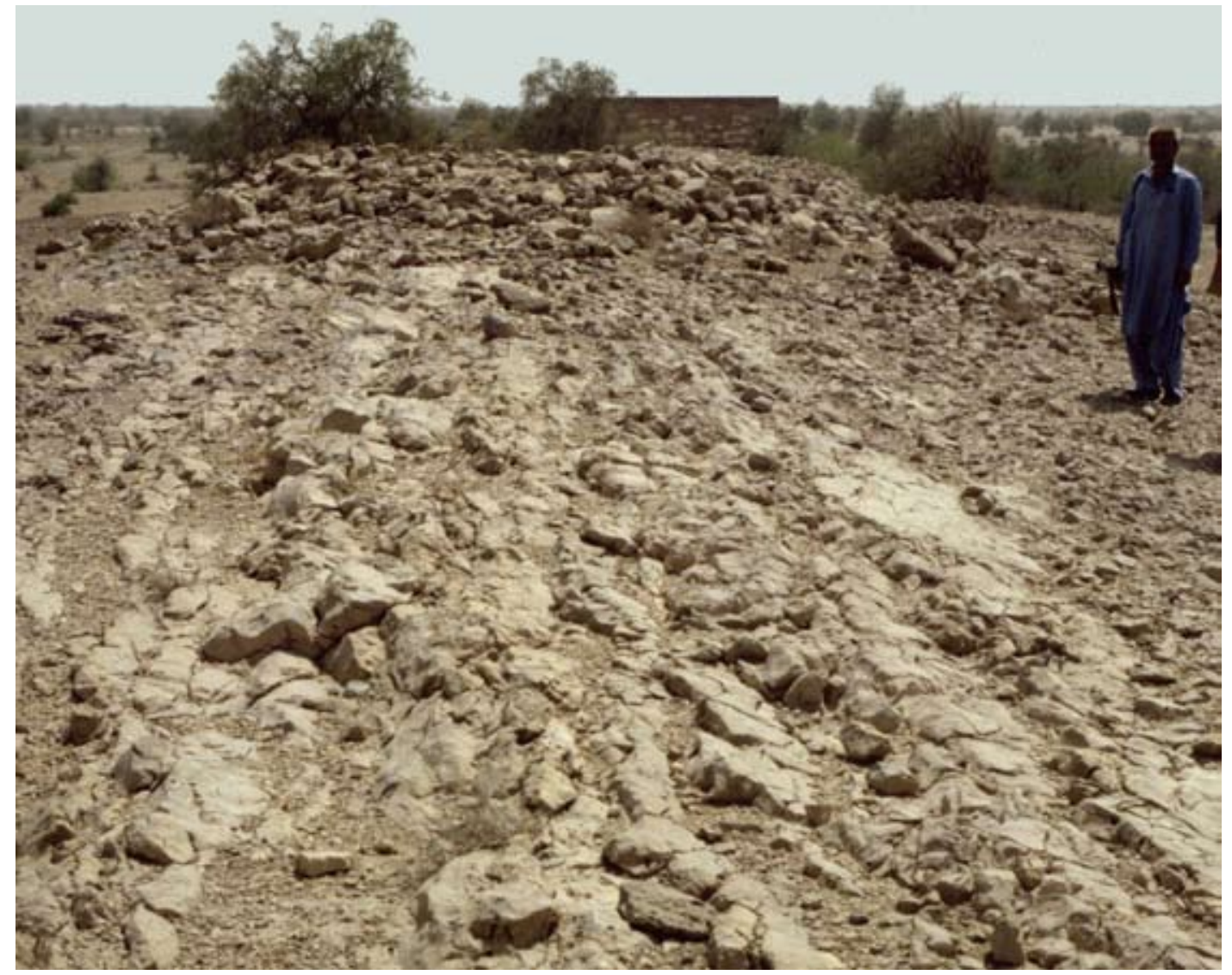

Figure 6. Photograph showing the view southward along the Band Virah fault, Pakistan. The Laki Limestone Member of the Laki Formation is on the right, the Manchhar Formation is on the left, and the Band Virah chauki (police station also shown in fig. 7) is in the background. The approximate location of the area is shown in figure 2 by the x. Photograph by W.F. Outerbridge (USGS, 1985). 


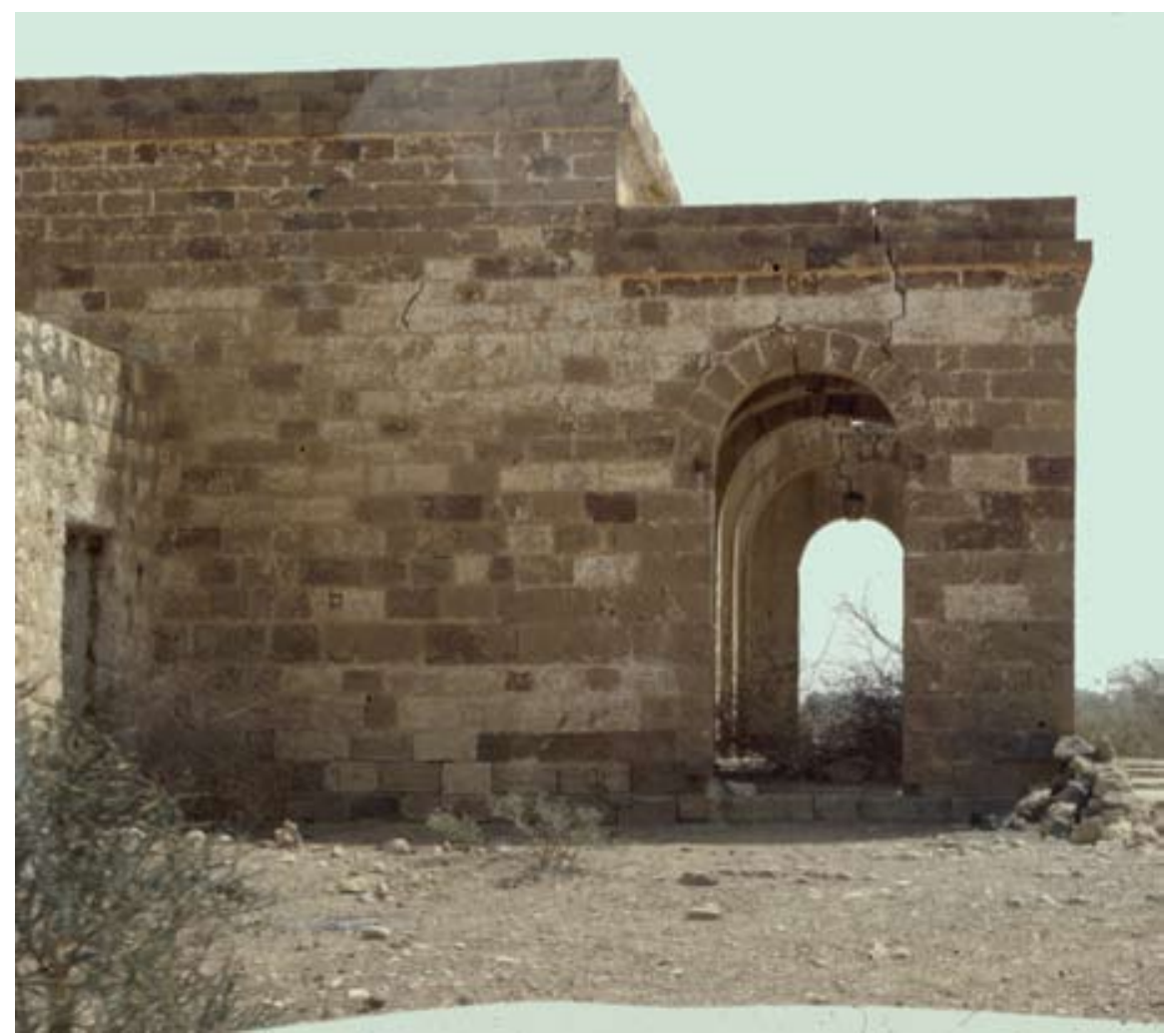

Figure 7. Photograph of the Band Virah chauki (police station), Pakistan. Broken arches and missing stones are attributed to earthquake damage after 1947. The building is visible in the background of figure 6 , and the approximate location of the area is shown in figure 2 by the x. Photograph by W.F. Outerbridge (USGS, 1985).

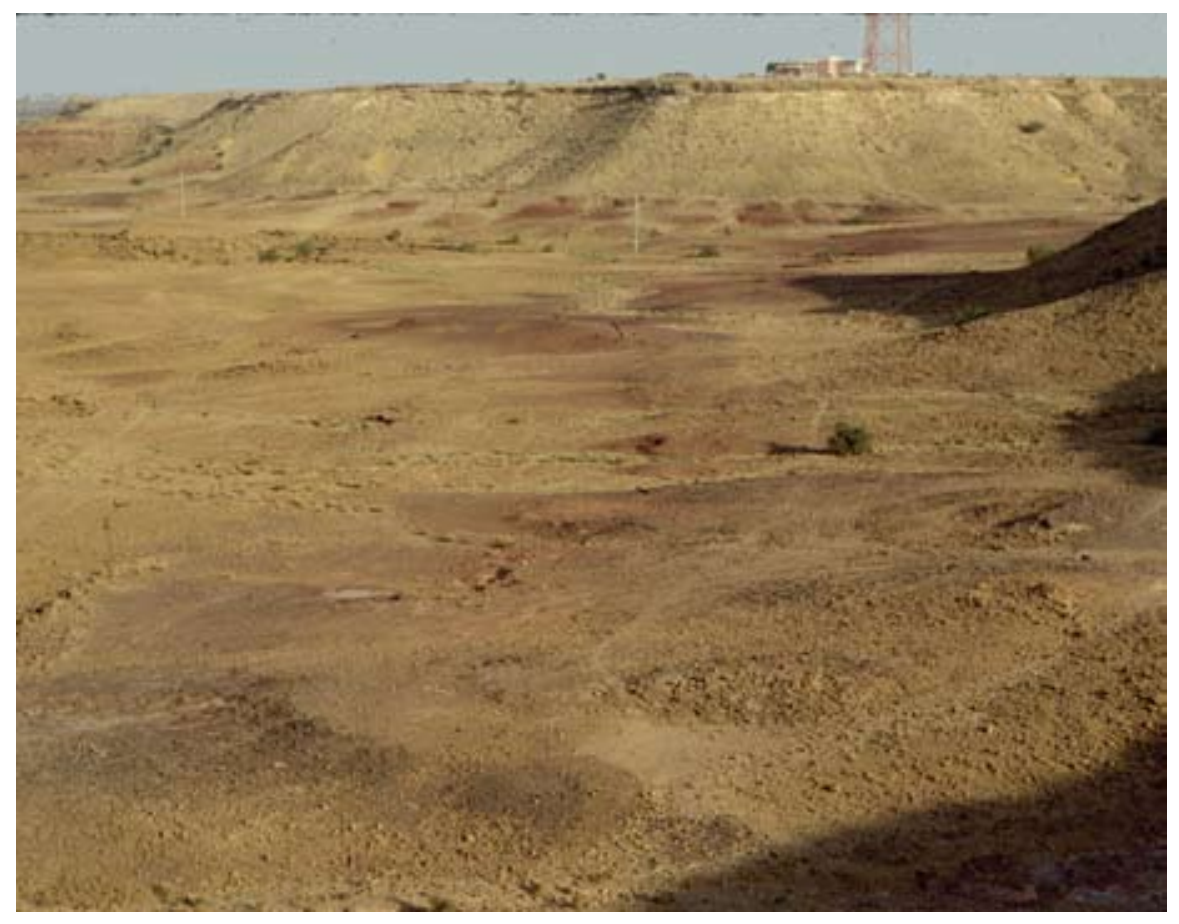

Figure 8. Photograph of the interior of the northeast side of the Lakhra anticline, Pakistan. The Lakhra Formation is the basal unit, the red unit at the base of the slope is the Sohnari Formation, and the hill slope and cap are composed of the Laki Formation. Photograph by W.F. Outerbridge (USGS, 1985). 


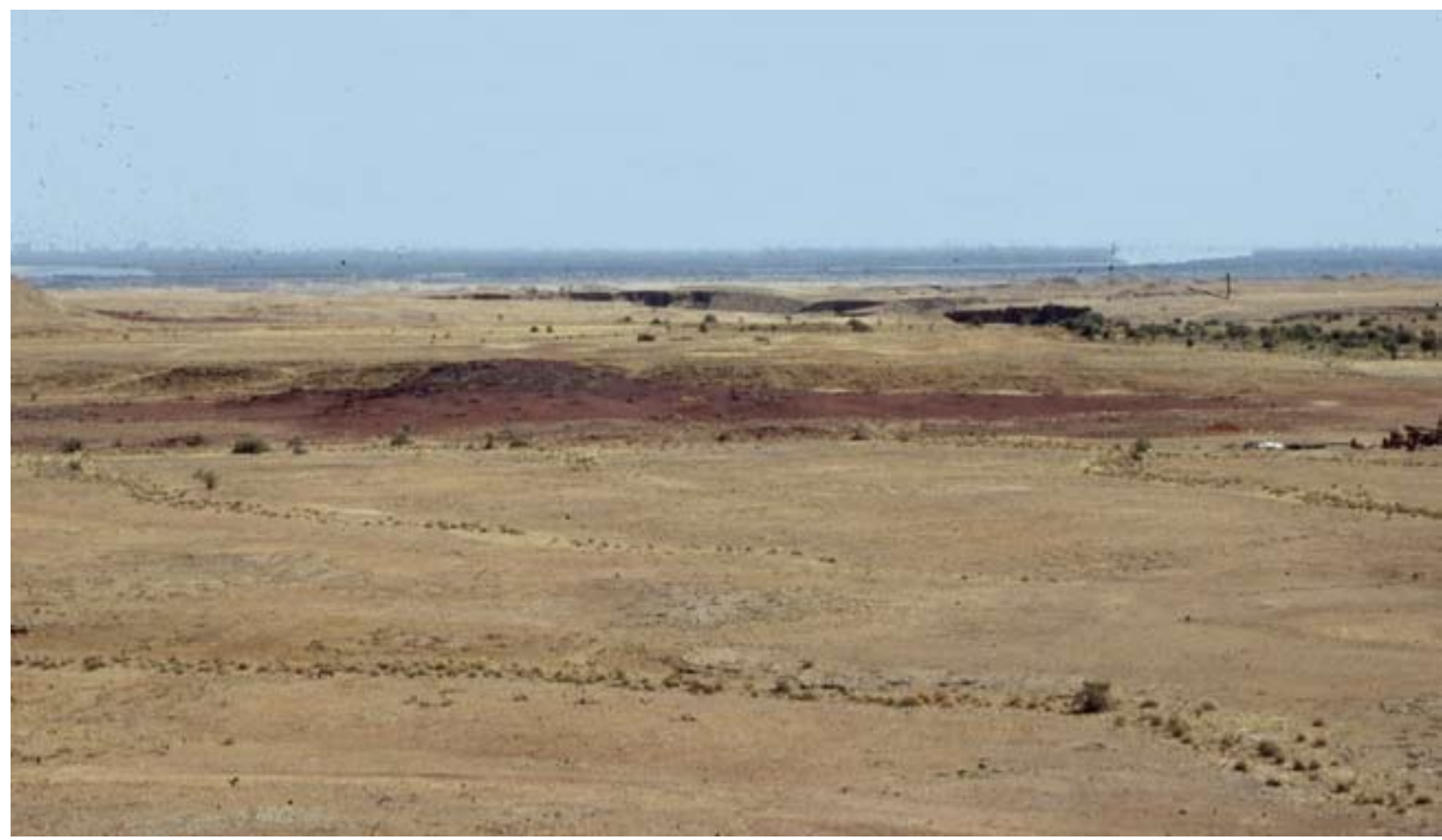

Figure 9. Photograph showing the view eastward down the dip slope on the Laki Formation, Pakistan. The red outcrop in the middle ground is the overlying Manchhar Formation. The Indus River and flood plain are in the background. Photograph by W.F. Outerbridge (USGS, 1985).



Figure 10. Photograph of Lakhra Nala, Pakistan, near its lower end. The steep bank is older alluvium, and the bed of the nala is younger alluvium. Photograph by W.F. Outerbridge (USGS, 1985). 


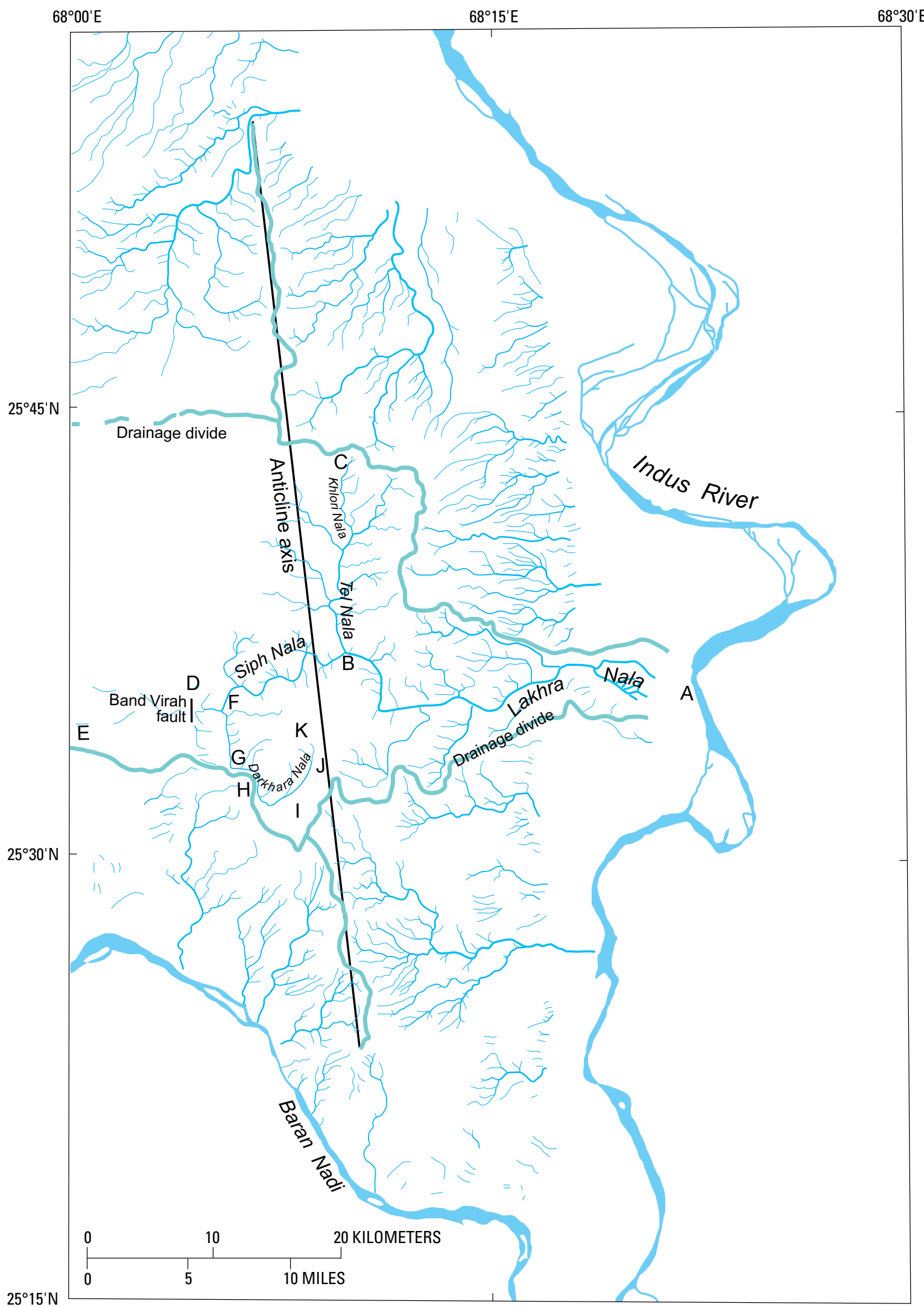

Figure 11. Drainage map of the Lakhra anticline, Pakistan, showing the trace of the anticline axis and all second-order and higher order drainages. Letters indicate corresponding points in this figure and figure 12. 




Figure 12. Profiles of selected drainages in the area of the Lakhra anticline, Pakistan. Letters indicate corresponding points in this figure and figure 11. 


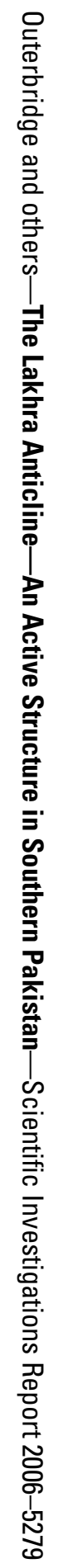

